\begin{tabular}{|c|c|}
\hline \multirow{3}{*}{ 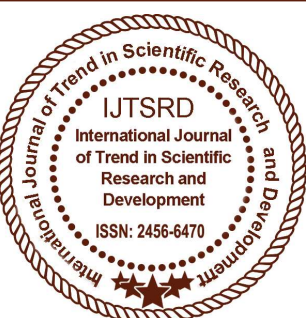 } & $\begin{array}{l}\text { International Journal of Trend in Scientific } \\
\text { Research and Development (IJTSRD) }\end{array}$ \\
\hline & Access Journal \\
\hline & ISSN No: 2456 - 6470 | www.ijtsrd.com | Volume - 2 | Issue -3 \\
\hline
\end{tabular}

\title{
A Comparative Study on Anaerobic Co-Digestion of Agricultural and Horticultural Waste
}

\author{
B. Prasanna Kumar*1 ${ }^{1}$, Dr. S. Triveni ${ }^{2}$, Dr. A. Vijaya Gopal ${ }^{3}$ \\ ${ }^{1 \& 2}$ Department of Agricultural Microbiology and Bioenergy, \\ Professor Jayashankar Telangana State Agricultural University (PJTSAU), \\ College of Agriculture, Rajendranagar, Hyderabad, Telangana, India \\ ${ }^{3}$ Department of Agricultural Microbiology, \\ Acharya N.G Ranga Agricultural University (ANGRAU), \\ Advanced Post Graduate Centre, Lam, Guntur, Andhra Pradesh, India
}

\section{ABSTRACT}

Agriculture, apart from crops and livestock, is a source of large amounts of troublesome by-products like different kinds of manure. Nevertheless, they could be successfully processed through anaerobic digestion technology, which allows for simultaneous waste utilization and energy generation. Production of biogas from manure only is low efficient due to the low dry matter content (about 8\%). The additional substrates, such as plants with high dry mass content, are used to improve the process efficiency. In this work biogas production technologies from different agricultural as well as horticultural feedstock was used along with the pretreatment with efficient cellulose degrading bacteria, a comparative experimental analysis between different types of biomass residues used for biogas production as estimation of biological oxygen demand (BOD), chemical oxygen demand (COD), cellulose, $\mathrm{pH}$, Nitrogen, Phosphorus and Potassium during the anaerobic fermentation process. The comparison is achieved using as parameter the biogas quality and quantity which are produced, using different available agricultural and horticultural waste material. All the measurements were made on a lab scale pilot installation.

Keywords: Anaerobic digestion technology, Pretreatment, Cellulose, Feedstock, BOD, COD

\section{INTRODUCTION}

Scenarios have shown that the energy demand will increase during this century by a factor of two or three, as result of the population growth and energy consumption per capita. At the same time, concentrations of greenhouse gases (GHGs) in the atmosphere are raising rapidly, the fossil fuel derived $\mathrm{CO}_{2}$ emissions being the most important contributor (Peter, 2009). Agricultural and Horticultural crop residues are generated in large quantities and constitute an abundant but underutilized source of renewable biomass in agriculture. The amount of crop residues available in India is estimated to be approximately 620 million tons.

The biogas production performance and the reasonable material ratio was analysed in order to provide the basis of the design and operation of anaerobic co-digestion process with cow manure, agricultural waste (AW) and horticultural waste (HW). Recently, large volume of cow dung generated from feedlot farming increases annually, most of which are disposed into landfills or are applied to the land without treatment. Anaerobic digestion of organic matter is recognized as an attractive and commercially viable option as a source of alternative energy. Methane can be obtained by anaerobic digestion of different organic matters including 
industrial residues, agricultural wastes, industrial wastewaters and municipal solid wastes. Biological pre-treatment were mainly focused on use of pure cultures, such as anaerobic bacteria, fungi, and Actinomycetes, which were able to degrade lignocelluloses. Different technologies are developed presently for the energy recovery of all types of wastes, one of them being the anaerobic fermentation process, which has as main product the biogas, considered a $\mathrm{CO}_{2}$ neutral gaseous fuel. Not all agricultural and food processing wastes have a high organic content that is amenable to biological treatment. Those with low organic content, insufficient nutrients, and which contain toxic compounds, require supplementary physical, chemical treatment, such as settlement, $\mathrm{pH}$ adjustment, chemical precipitation, coagulation, reverse osmosis, ion exchange, or adsorption. However, biological treatment, particularly anaerobic, is often the best and/or most cost effective alternative for economical pretreatment (Hansen and Cheong, 2007). Anaerobic digestion and biogas production are promising means of achieving multiple environmental benefits and producing an energy carrier from renewable resources. Replacing fossil fuels with biogas normally reduces the emission not only of greenhouse gases, but also of nitrogen and sulfur oxides, hydrocarbons, and particles (Borjesson and Berglund, 2006). Anaerobic digestion consists of a series of processes in which microorganisms break down biodegradable material in the absence of oxygen, used for industrial or domestic purposes to manage waste and/or to release energy. It is widely used as part of the process to treat waste water. As part of an integrated waste management system, anaerobic digestion reduces the emission of landfill gas into the atmosphere.

Anaerobic digestion is widely used as a renewable energy source because the process produces a methane and carbon dioxide rich biogas suitable for energy production, helping to replace fossil fuels. The nutrient-rich digestate which is also produced can be used as fertilizer. The digestion process begins with bacterial hydrolysis of the input materials in order to break down insoluble organic polymers such as carbohydrates and make them available for other bacteria. Acidogenic bacteria then convert the sugars and amino acids into carbon dioxide, hydrogen, ammonia, and organic acids. Biogas is considered to become one of the most important alternative fuels and will potentially replace partially natural gas and oil. No negative or limited environmental side effects are observed, because biogas can be produced from all types of "green" biomass (Busch et al. 2009). Anaerobic co-digestion strategies has become the development trend of biogas engineering (Maranon et al. 2012 and Amon et al. 2007). However, most of the lab research and engineering project only stay on the two kinds of material mixed fermentation (5 7). Therefore, this study selected cow manure and maize straw anaerobic digestion system to add vegetable waste as the third mixed material. Under mesophilic condition $\left(37 \pm 1{ }^{0} \mathrm{C}\right)$, a bench-scale experiment based on anaerobic co-digestion process of this ternary mixtures was conducted in a fed-batch single phase reactors. The biogas production performance and the reasonable material ratio was analyzed in order to provide the basis of the design and operation of anaerobic co-digestion process with cow manure, maize straw and vegetable waste. This paper demonstrates the application of a two-phase anaerobic digestion system where co-digestion of various agricultural and municipal organic solid wastes was evaluated. Digestion of single wastes (OFMSW and $\mathrm{CM}$ ) was investigated in separate experiments to assess the effect of co-digestion.

\section{MATERIALS AND METHODS}

The material and the methods adopted during the course of investigation are presented in this chapter. Analysis was conducted in the Department of Agricultural Microbiology and Bio-energy, College of Agriculture, PJTSAU, Rajendranagar, Hyderabad.

\subsection{Isolation and identification of cellulose degrading bacteria:}

Isolation of cellulolytic bacteria cellulolytic bacterial strains were isolated from soil by usingserial dilutions and pour plate technique. The medium used for isolation of cellulolytic bacteria contains $1.0 \%$ peptone, $1.0 \%$ carboxymethyl cellulose (CMC), 0.2 $\% \mathrm{~K}_{2} \mathrm{HPO}_{4}, 1 \%$ agar, $0.03 \% \mathrm{MgSO}_{4} .7 \mathrm{H}_{2} \mathrm{O}, 0.25 \%$ $\left(\mathrm{NH}_{4}\right)_{2} \mathrm{SO}_{4}$ and $0.2 \%$ Gelatin at $\mathrm{pH} 7$ for 48 hours of incubation at $30{ }^{0} \mathrm{C}$ (Yin et al., 2010). Bacterial colonies were purified by repeated streaking. The purified colonies were preserved at $40 \mathrm{C}$ for further identification and screening for cellulase production.

\subsection{Screening of cellulolytic bacteria}

Pure cultures of bacterial isolates were individually transferred in CMC agar plates. After incubation for 48 hours, CMC agar plates were flooded with $1 \%$ 
congored and allowed to stand for $15 \mathrm{~min}$ at room temperature. One molar $\mathrm{NaCl}$ was thoroughly used for counterstaining the plates. Clear zones were appeared around growing bacterial colonies indicating cellulose hydrolysis (Andro et al., 1984). The bacterial colonies having the largest clear zone were selected for identification and cellulase production in submerged system.

\subsection{Cellulase activity test for the isolates:} Cellulase activity was assayed using dinitrosalicylic acid (DNS) reagent (Miller, 1959)by estimation of reducing sugars released from CMC solubilized in $0.05 \mathrm{M}$ phosphate buffer at $\mathrm{pH} 8$ (Bailey et al., 1992). The culture broth was centrifuged at $14000 \times \mathrm{g}$ for 10 min at $4{ }^{0} \mathrm{C}$ and the clear supernatant served as crude enzyme source. Crude enzyme was added to $0.5 \mathrm{ml}$ of $1 \% \mathrm{CMC}$ in $0.05 \mathrm{M}$ phosphate buffer and incubated at $50{ }^{0} \mathrm{C}$ for $30 \mathrm{~min}$. After incubation, reaction was stopped by the addition of $1.5 \mathrm{ml}$ of DNS reagent and boiled at $100{ }^{0} \mathrm{C}$ in water bath for $10 \mathrm{~min}$. Sugars liberated were determined by measuring absorbance at $540 \mathrm{~nm}$. Cellulase production was estimated by using glucose calibration curve (Shoham et al., 1999). One unit (U) of enzyme activity is expressed as the quantity of enzyme, which is required to release $1 \mu \mathrm{mol}$ of glucose per minute under standard assay conditions.

\subsection{Procedure for pretreatment}

First, $1 \mathrm{~g}$ dry ground corn straw powder was poured into a118 $\mathrm{ml}$ serum glass bottle, after which $10 \mathrm{ml}$ distilled water was added into the bottle. After autoclaving for $120 \mathrm{~min}$, the bottles were inoculated with the complex microbial agents in aseptic conditions. A $0.01 \%(\mathrm{w} / \mathrm{w})$ dose of the complex microbial agents was used in our study. Each of 20 bottles was then covered and sealed with a plastic film. A sponge plug was inserted into the middle of the film to sparge air while preventing airborne microorganisms from entering the bottle. The control bottle was not inoculated with complex microbial agents. It only contained $1 \mathrm{~g}$ dry ground corn straw and $10 \mathrm{ml}$ distilled water. The bottles were placed in an incubation chamber. Samples were obtained on the 0th, 5th, 10th, 15th, and 20th day of incubation for composition determination, chemical analyses, and biochemical methane potential (BMP) assay.

\subsection{Reactor set-up}

Biogas production was studied in the lab with four treatments and three replications each and with 250 grams cattle dung, 500 grams substrate and $1000 \mathrm{ml}$ water (1:2:5). A completely recycled anaerobic glass bottle made from cylindrical column of borosilicate glass with total volume of $3 \mathrm{~L}$ was utilized in the study. The glass bottle was blanketed with a corkborer to avoid entry of direct sunlight and escape of process heat. Reactor system for anaerobic fermentation with arrangement for feed, recirculation and biogas measurement is made by using 1 liter container (Measuring cylinder), Solid tape, $\mathrm{M}$ - seal, Rubber or plastic cape (to seal container), Funnel (for feed input), Cape 0.5" (to seal effluent pipe), Pipe (for gas output, I was used level pipe) (3-5 m), Bucket (15-20 litter) and Bottle - for gas collection (2-10 lit.

\subsection{Reactor operation}

The maize straw and cattle dung slurry was fed to the reactor from the top by a one way funnel and the equal quantity of the reactor digestate was withdrawn for the physico chemical analysis. The complete recycle was done to obtain complete mixing/agitation of the reactor digestate. The controlled up flow pattern of maize starw with cattle dung slurry through the reactor renders stratification of the phases such as hydrolysis, acidogenesis and methanogenesis. Such a pattern of single phase reactor operation provides advantages of two phase reactor.

\subsection{Inoculum}

Cattle dung slurry along with some cellulose degrading bacterial consortium was used as a source of inoculum since rumen of cattle dung contains anaerobic microbial population. The cow dung slurry was prepared by mixing water in 1:2:5 proportions and sieved to remove coarse particles. The cow dung slurry and the starw were mixed in 1:2 proportion and the mix was poured in the reactor. The reactor content was mixed thoroughly by $100 \%$ recirculation from the outlet (top) to the inlet (bottom) of the reactor with manual stirring process.

\subsection{Anaerobic digestion tests}

The biodegradability and biogas yield of feedstock were determined at $37{ }^{\circ} \mathrm{C}$ using three batches anaerobic digestion tests with the total volume of each reactor $3 \mathrm{~L}$. Cellulose degrading bacterial consortium used as inoculums for the anaerobic reactors. The dosage of substrate was adjusted by VSS content to avoid overloading of reactors. Daily biogas production from each digester was measured by using measuring cylinder. Along with the estimation of biogas production different parameters like Total Solids (TS \%), Total Volatile Solids (TVS \%), Volatile Fatty Acids (VFA), pH, Nitrogen ( $\mathrm{N} \%$ ), 
Phosphorous (P \%), Potassium (K \%), Organic carbon, Biological Oxygen Demand (BOD), Chemical Oxygen Demand (COD), cellulose \%, microbial population count, methane and bioethanol percentage were estimated.

\subsection{Estimation of $\mathrm{pH}$ in the slurry samples} $\mathrm{pH}$ of the slurry samples were determined in 1:2.5 substrate:water suspension by using digital $\mathrm{pH}$ meter (Systronics $\mu \mathrm{pH}$ system361) (Jackson, 1973).

\subsection{Estimation total Nitrogen content in the slurry samples}

Total nitrogen in slurry samples were estimated by modified Kjeldahl method using sulphuric and salicylic acid mixture. One gram of slurry sample was taken into $100 \mathrm{ml}$ conical flask, $30 \mathrm{ml}$ of sulphuric acid - salicylic acid mixture and $0.5 \mathrm{~g}$ of sodium thiosulphate was added mixed well and kept aside for half an hour and digested on flame. After $30 \mathrm{~min}$ of digestion, one gram of copper sulphate and $10 \mathrm{~g}$ of potassium sulphate was added, digestion was continued till colourless solution obtained. The digested material was washed with distilled water and only supernatant liquid was transferred to a beaker. From that beaker solution was transferred to kjeldhal flask. $50 \mathrm{ml}$ of $4 \%$ boric acid taken into $250 \mathrm{ml}$ conical flask to which two drops of mixed indicator was added and kept at the flask at the receiving end of distillation set in such a way that the receiving end immersed into the solution. Few $\mathrm{Zn}$ pieces, little quantity of paraffin and $120 \mathrm{ml}$ of $40 \% \mathrm{NaOH}$ was added to the Kjeldhal flask and immediately mouth of the flask was closed. The distillation continued till no more ammonia was evolved at the receiving end of the distillation set. At the end of distillation, the tip of receiving end was washed with distilled water, contents of the flask were cooled and titrated against $0.01 \mathrm{~N} \mathrm{H}_{2} \mathrm{SO}_{4}$ till blue colour changed to pinkish red colour.

Burette reading was noted and nitrogen $\%$ was calculated as:

Weight of the plant sample taken $\quad=0.1 \mathrm{~g}$

Blank titre value $=\mathrm{B} \mathrm{ml}$ of $0.01 \mathrm{~N}$

$\mathrm{H}_{2} \mathrm{SO}_{4}$

Sample titre value $=\mathrm{S} \mathrm{ml}$ of $0.01 \mathrm{~N}$ $\mathrm{H}_{2} \mathrm{SO}_{4}$

Actual titre value
$1000 \mathrm{ml}$ of $1 \mathrm{~N} \mathrm{H}_{2} \mathrm{SO}_{4}$ $=14 \mathrm{~g} \mathrm{~N}$

$(\mathrm{S}-\mathrm{B}) \mathrm{ml}$ of $0.01 \mathrm{~N} \mathrm{H}_{2} \mathrm{SO}_{4}$ $=\frac{(\mathrm{S}-\mathrm{B}) 0.01 \times 14}{1000}$

Present in $0.1 \mathrm{~g}$ plant sample

$100 \mathrm{~g}$ of plant sample contains

(S-B) $0.01 \times 14 \times 100 \mathrm{~g}$ of N

$1000 \times 0.1$

$=(\mathrm{S}-\mathrm{B}) \times 0.14$

$\%$ of $\mathrm{N}$

\subsection{Estimation total Phosphorus content in the slurry samples}

Total phosphorus content in slurry samples were determined by perchloric acid digestion method using Barton's reagent as described by Jackson (1967). One gram of slurry sample was taken into $100 \mathrm{ml}$ conical flask and 12-15 $\mathrm{ml}$ of tri acid mixture was added (Nitric acid: Sulphuric acid: Perchloric acid at 9:2:1). The mouth of the flask was covered with a funnel. The contents were digested over a sand bath till clear solution was obtained. The filtrate was collected and 5 $\mathrm{ml}$ was taken into $25 \mathrm{ml}$ volumetric flask and $5 \mathrm{ml}$ of Barton's reagent was added and volume made up to $25 \mathrm{ml}$ with distilled water. Yellow colour was developed in 30 minutes and intensity of colour was measured in a photoelectric colorimeter using blue filter $(470 \mathrm{~nm})$. The colour will be stable for $24 \mathrm{~h}$. Standard curve was prepared and the concentration of phosphorus in the solution was deduced from that value and the percentage of phosphorus in the sample was calculated.

Concentration of phosphorus in coloured solution $=\mathrm{X}$ ppm

i.e., $1 \mathrm{ml}$ of coloured solution contains $=\mathrm{X} \mu \mathrm{g} \mathrm{P}$

$50 \mathrm{ml}$ of coloured solution contains $\quad=50 \times \mathrm{X} \mu \mathrm{g} \mathrm{P}$

Which is present in $5 \mathrm{ml}$ of the diluted digest

$100 \mathrm{ml}$ of diluted plant digest contains of $50 \times \mathrm{X} \times \frac{100}{5}$ $=\mathrm{X} \times 1000 \mu \mathrm{g} \mathrm{P}$

Which is obtained from $1 \mathrm{~g}$ sample

$100 \mathrm{~g}$ of sample consists of $=\mathrm{X} \times 1000 \times \frac{100}{1}$

$=\mathrm{X} \times 10^{5} \times 10^{-6} \%$ of $\mathrm{P}$

$=\mathrm{X} \times 0.1 \%$ 


\subsection{Estimation total Potassium content in the slurry samples}

Tri-acid extract was directly aspirated to the flame photometer to estimate the total potassium content (Systronics flame photometer 128) by Jackson (1967). $5 \mathrm{ml}$ of tri-acid extract was taken into $25 \mathrm{ml}$ volumetric flask and volume made upto the mark with distilled water. The concentration of $\mathrm{K}$ in the solution was measured using flame photometer. Standard curve was prepared and the concentration of $\mathrm{K}$ in the solution was deduced from that value and the percentage of $\mathrm{K}$ in the sample was calculated. Amount of $\mathrm{K}$ present in the sample $(\%$ of $\mathrm{K})=$

Concentration of $\mathrm{K}$ in the sample $=\mathrm{X}$ ppm

$1 \mathrm{ml}$ of the sample

$=\mathrm{X} \mu \mathrm{g}$ of $\mathrm{K}$

$100 \mathrm{ml}$ of the sample

$=$ ?

K

$1 \mathrm{~g}$ of sample

$100 \mathrm{~g}$ of sample

$\mu \mathrm{g}$ of $\mathrm{K}$

K
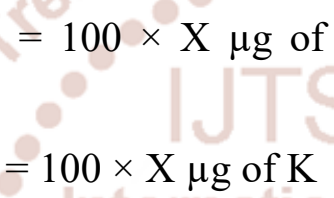

$=?$

$=\frac{100}{1} \times 100 \times \mathrm{X}$

$=\mathrm{X} \times 10^{4} \times 10^{-6} \mathrm{~g}$

\subsection{Biological Oxygen Demand (BOD)}

Biological Oxygen Demand was determined by measuring oxygen concentration in slurry sample, idometrically before and after incubation in the dark at $20{ }^{0} \mathrm{C}$ for 5 days by the colorimetric method (APHA, 1992). BOD bottles were taken and filled with the sample and stopper was placed. Then the stopper was removed and $1 \mathrm{ml}$ of each manganous sulphate and alkaline potassium sulphate were added. Precipitation was dissolved by adding $2 \mathrm{ml}$ of sulphuric acid. Then the whole content was transferred into a conical flask. Few drops of starch indicator was added and titrated against sodium thiosulphate solution till the initial blue colour turned to colourless. The titre value obtained gives dissolved Oxygen (D. $\left.\mathrm{O}_{1}\right)$

Dissolved Oxygen $\left(\right.$ D. $\left.\mathrm{O}_{1}\right)=\frac{(\mathrm{V} 1 \mathrm{~N} \times 8 \times 1000)}{\mathrm{V} 2-\mathrm{V} 3}$

Volume of titrant $(\mathrm{ml})=\mathrm{V}_{1}$

Volume of sampling bottle after placing the stopper $(\mathrm{ml})=\mathrm{V}_{2}$

Volume of manganous sulphate and potassium sulphate solution added $(\mathrm{ml})=\mathrm{V}_{3}$

Other set of BOD bottles were prepared same as above and incubated in BOD incubator for 5 days. After 5 days the content from BOD bottles were transferred into conical flasks and titrated similarly. The dissolved oxygen content D. $\mathrm{O}_{5}$ was determined.

$\mathrm{BOD}=\left(\mathrm{D} . \mathrm{O}_{1}-\mathrm{D} . \mathrm{O}_{5}\right) \times$ dilution factor

\subsection{Chemical Oxygen Demand (COD)}

Chemical Oxygen Demand was determined by taking centrifuged slurry samples and refluxed with a known amount of Potassium dichromate in sulphuric acid medium and excess of dichromate was titrated against ferrous ammonium sulphate. The amount of dichromate consumed was proportional to the oxygen required to oxidize the organic matter. Chemical oxygen demand was determined by the closed reflux colorimetric method (APHA, 1992).

$\mathrm{COD}=\frac{(\mathrm{B}-\mathrm{T}) \times \mathrm{N} \times 1000 \times 8}{\text { Volume of sample }(\mathrm{ml})}$

\subsection{Estimation of cellulose}

Cellulose content was estimated by the method of Uppdegraff (1969). Hundred milligram of pretreated cellulose wastes were added with $5 \mathrm{ml}$ of Nitric reagent and boiled and cooled. It was centrifuged at $5000 \mathrm{rpm}$ for $5 \mathrm{~min}$. The pellet was washed with distilled water. $10 \mathrm{ml}$ of $67 \%$ sulphuric acid was added. One $\mathrm{ml}$ of the sample was diluted to $100 \mathrm{ml}$. To $1 \mathrm{ml}$ of the each diluted solution, $10 \mathrm{ml}$ of freshly prepared ice cooled anthrone reagent was added and boiled in a boiling water bath for $10 \mathrm{~min}$ at $100{ }^{0} \mathrm{C}$. After that absorbance was recorded at $600 \mathrm{~nm}$.

\subsection{Measurement of Gas production}

The biogas production readings were taken on an alternate day by water displacement method with the measuring jar.

\subsubsection{Estimation of methane percentage using gas chromatography}

Methane percentage in the biogas was estimated by using gas chromatography (Bruker-450) with a Flame 
Ionization Detector (FID) temperatures were maintained at $300{ }^{\circ} \mathrm{C}$ in the detector, $75{ }^{\circ} \mathrm{C}$ in the injector and $50{ }^{\circ} \mathrm{C}$ in the oven. The column used was porapak Q. The gas flow in the column was maintained as $60 \mathrm{ml} \mathrm{min}^{-1}$.

\section{RESULTS:}

Table 1. Different isolates of soil and waste samples and their cellulase activity

\begin{tabular}{|c|c|c|c|c|}
\hline S.No & Sample & $\begin{array}{c}\text { Isolate. } \\
\text { No }\end{array}$ & $\begin{array}{c}\text { Cellulase } \\
\text { activity } \\
\text { zone } \\
(\mathbf{m m})\end{array}$ & $\begin{array}{c}\text { Cellulase } \\
\text { activity } \\
\text { (mg/ml) }\end{array}$ \\
\hline 1 & Soil & PS-1 & 1.250 & 0.353 \\
\hline 2 & Soil & BCS-5 & 1.175 & 0.354 \\
\hline 4 & $\begin{array}{c}\text { Domestic } \\
\text { Kitchen } \\
\text { Waste }\end{array}$ & DKW & 1.375 & 0.362 \\
& $\begin{array}{c}\text { Sewage } \\
\text { Water } \\
\text { Sample }\end{array}$ & SWS & 1.125 & 0.350 \\
\hline
\end{tabular}

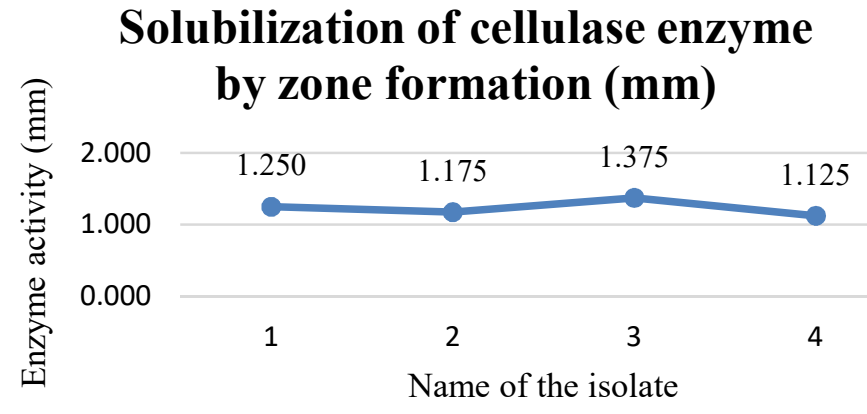

Fig 1. Qualitative estimation of cellulase enzyme activity

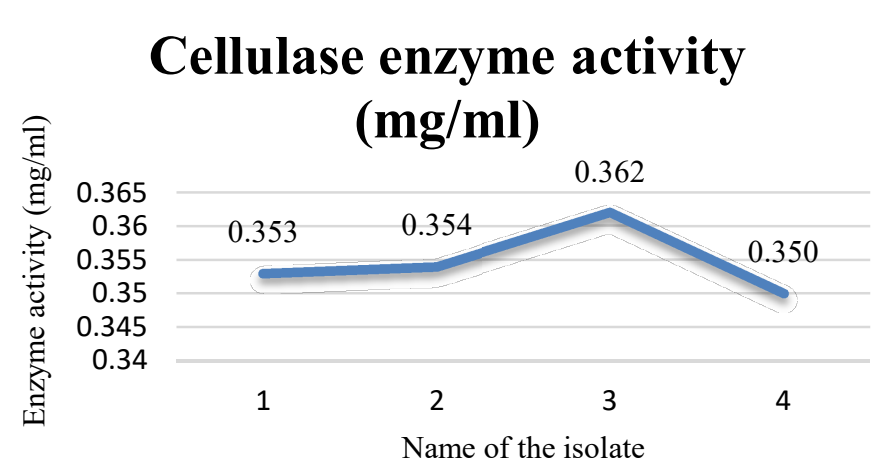

Fig 2. Quantitative estimation of cellulase enzyme activity

Table 2. Operational parameters during the experiment along with production of biogas from agricultural and horticultural waste

\begin{tabular}{|c|c|c|c|c|c|c|c|c|c|c|c|c|}
\hline \multirow[b]{2}{*}{ Treatments } & \multicolumn{5}{|c|}{ Biogas production (\%) SS: 24} & \multirow[b]{2}{*}{$\begin{array}{c}\text { BOD } \\
\left(\mathrm{mg} \mathrm{l}^{-1}\right)\end{array}$} & \multirow[b]{2}{*}{$\begin{array}{l}\text { COD } \\
\left(\mathrm{g} \mathrm{I}^{-1}\right)\end{array}$} & \multirow{2}{*}{$\begin{array}{l}\text { Cellu } \\
\text { lose } \\
(\%)\end{array}$} & \multirow[b]{2}{*}{ pH } & \multirow[b]{2}{*}{$\begin{array}{c}\text { Nitro } \\
\text { gen } \\
(\%)\end{array}$} & \multirow[b]{2}{*}{$\begin{array}{c}\text { Phosphoru } \\
\text { s (\%) }\end{array}$} & \multirow[b]{2}{*}{$\begin{array}{c}\text { Potassiu } \\
\text { m (\%) }\end{array}$} \\
\hline & $0^{\text {th }}$ day & $\begin{array}{l}15^{\text {th }} \\
\text { day }\end{array}$ & $\begin{array}{l}30^{\text {th }} \\
\text { day }\end{array}$ & $\begin{array}{l}45^{\text {th }} \\
\text { day }\end{array}$ & $\begin{array}{l}\mathbf{6 0}^{\text {th }} \\
\text { day }\end{array}$ & & & & & & & \\
\hline $\begin{array}{c}\mathrm{AW}-\mathrm{T}_{1}-\mathrm{M}_{1}- \\
\mathrm{C}_{1}\end{array}$ & $\begin{array}{l}550.00 \\
(57.51)\end{array}$ & $\begin{array}{l}720.30 \\
(58.12)\end{array}$ & $\begin{array}{l}980.20 \\
(59.02)\end{array}$ & $\begin{array}{l}580.00 \\
(46.20)\end{array}$ & $\begin{array}{l}550.50 \\
(16.48)\end{array}$ & 101 & & 16.00 & 8.19 & 0.76 & 0.17 & 0.72 \\
\hline $\begin{array}{c}\mathrm{AW}-\mathrm{T}_{2}-\mathrm{M}_{1}- \\
\mathrm{C}_{2}\end{array}$ & $\begin{array}{l}680.30 \\
(21.45)\end{array}$ & $\begin{array}{l}700.20 \\
(22.08)\end{array}$ & $\begin{array}{l}950.30 \\
(20.79)\end{array}$ & $\begin{array}{l}620.30 \\
(19.56)\end{array}$ & $\begin{array}{l}580.00 \\
(15.06)\end{array}$ & 118 & 109 & 16.56 & 8.26 & 0.98 & 0.19 & 0.78 \\
\hline $\begin{array}{c}\mathrm{HW}-\mathrm{T}_{3}-\mathrm{M}_{1}- \\
\mathrm{C}_{1}\end{array}$ & $\begin{array}{l}500.60 \\
(51.74)\end{array}$ & $\begin{array}{l}580.30 \\
(54.30)\end{array}$ & $\begin{array}{l}500.20 \\
(57.56)\end{array}$ & $\begin{array}{l}420.00 \\
(45.08)\end{array}$ & $\begin{array}{l}380.30 \\
(34.12)\end{array}$ & 121 & 113 & 15.85 & 8.14 & 1.48 & 1.06 & 0.94 \\
\hline $\begin{array}{c}\mathrm{HW}-\mathrm{T}_{4}-\mathrm{M}_{1}- \\
\mathrm{C}_{2}\end{array}$ & $\begin{array}{l}490.20 \\
(51.52)\end{array}$ & $\begin{array}{l}600.20 \\
(53.96)\end{array}$ & $\begin{array}{l}580.00 \\
(54.13)\end{array}$ & $\begin{array}{l}500.30 \\
(44.96)\end{array}$ & $\begin{array}{l}450.00 \\
(35.15)\end{array}$ & 134 & 110 & 15.32 & 8.48 & 1.28 & 1.96 & 0.89 \\
\hline
\end{tabular}


*The table values with in the brackets indicate the composition of methane per cent of different treatments.

AW- Agricultural waste

$\mathrm{AW}-\mathrm{T}_{1}-\mathrm{M}_{1}-\mathrm{C}_{1}-$ Biogas production without pretreatment

$\mathrm{AW}-\mathrm{T}_{2}-\mathrm{M}_{1}-\mathrm{C}_{2}-$ Biogas production with pretreatment

HW- Horticultural waste

$\mathrm{HW}-\mathrm{T}_{3}-\mathrm{M}_{1}-\mathrm{C}_{1}-$ Biogas production without pretreatment

$\mathrm{HW}-\mathrm{T}_{4}-\mathrm{M}_{1}-\mathrm{C}_{2}-$ Biogas production with pretreatment

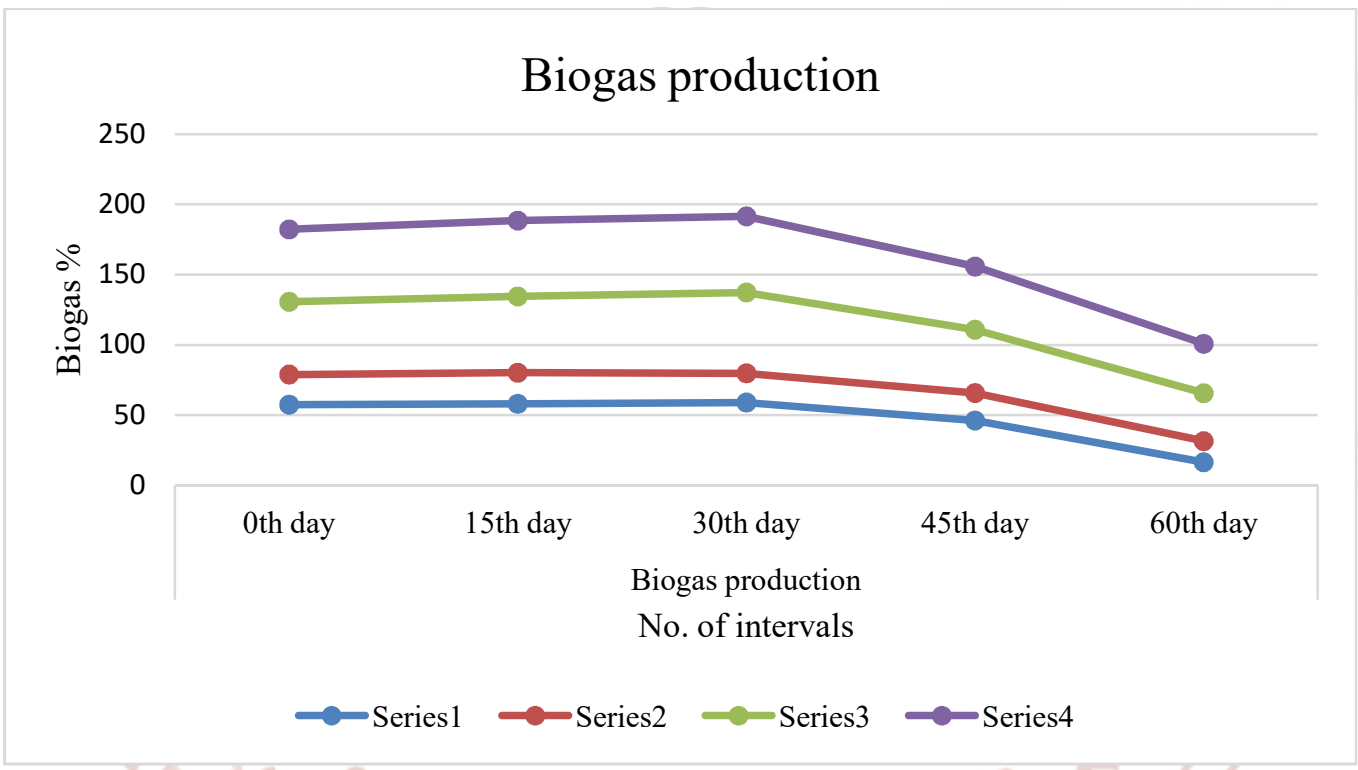

Fig 3. Production of biogas from agricultural and horticultural waste

\subsection{Isolation, screening and cellulase activity}

Cellulose degrading bacteria was isolated from different soil samples and waste samples [Soil samples of farmer fields, Domestic Kitchen Waste (DKW) and Sewage Water Sample (SWS)] by using CMC agar medium. Total number of cellulose degrading bacterial colonies were counted. Among all the samples of soil, DKW and SWS samples four different efficient cellulose degrading bacteria were screened based on morphological and biochemical characteristics these isolates are also tested for their efficient cellulase degrading capacity by qualitative and quantitative studies. Among the four isolates DKW showed maximum cellulase activity by formation of solubilisation zone of $1.375 \mathrm{~mm}(0.362$ $\mathrm{mg} / \mathrm{ml}$ ) (Fig 1 \& 2) as when compared to PS-1 has $1.250 \mathrm{~mm}(0.353 \mathrm{mg} / \mathrm{ml})$, BCS-5 has $1.175 \mathrm{~mm}$ (0.354) and SWS has showed $1.125 \mathrm{~mm}(0.350$ $\mathrm{mg} / \mathrm{ml}$ ) (Table 1). Gautam et al. (2012) studied diversity of cellulolytic microbes and biodegradation of municipal solid waste by a potential strain.

\subsection{Biogas production from Agricultural and Horticultural waste enriched with and without cellulose degrading bacteria}

All the biogas production units with four treatments and three replications were set on the same day with 250 grams cow dung, 500 grams substrate and 1000 $\mathrm{ml}$ water $(1: 2: 5$ ratio).

The results of biogas production revealed that, the end of the $7^{\text {th }}$ day in AW-T (Biogas production with pretreatment) $680.30 \mathrm{ml}$ of biogas was released followed by $(550.00 \mathrm{ml})$ in $\mathrm{AW}-\mathrm{T}_{1}$ (Biogas production without pretreatment) (Fig 3). At the end of $15^{\text {th }}$ day $720.30 \mathrm{ml}$ of biogas was released in AW$\mathrm{T}_{1}$ (Biogas production without pretreatment) and lower amount was observed in $\mathrm{HW}-\mathrm{T}_{1}$ (Biogas 
production without pretreatment $)(580.30 \mathrm{ml})$. At the end of $30^{\text {th }}$ day in $\mathrm{AW}-\mathrm{T}_{1}$ (Biogas production without pretreatment) more amount of biogas was evolved $(620.30 \mathrm{ml})$. At the end of $60^{\text {th }}$ day highest gas production was observed in $\mathrm{AW}-\mathrm{T}_{2}$ (Biogas production with pretreatment) $(580.00 \mathrm{ml})$. Based on the water displacement readings more biogas evolved in $\mathrm{AW}-\mathrm{T}_{1}$ (Biogas production without pretreatment) at $15^{\text {th }}$ day $(550.00 \mathrm{ml}), 30^{\text {th }}$ day $(980.20 \mathrm{ml}), \mathrm{AW}-\mathrm{T}_{2}$ (Biogas production with pretreatment) having more biogas evolution at $7^{\text {th }}$ day $(680.30 \mathrm{ml}), 45^{\text {th }}$ day $(620.30 \mathrm{ml})$ and $60^{\text {th }}$ day $(580.00 \mathrm{ml})$ (Table 2).

The above results were similar to that of Vikrant and Shekar. (2013) who studied on the anaerobic digestion of horticulture waste for production of biogas with combination of the mixed inoculum was used for biogas production at $37{ }^{\circ} \mathrm{C}$ in laboratory (small scale) reactor and results were obtained as in between 10 to $150 \mathrm{ml}$ during the process of anaerobic digestion. In the above result methane $\left(\mathrm{CH}_{4}\right)$ in the four treatments was similar to that of Ziganshin et al. (2013) who conducted an experiment was anaerobic digestion in laboratory scale biogas reactors fed with different agricultural waste materials and obtained the results of methane $\left(\mathrm{CH}_{4}\right)(57.50,51.70$ and $44.20 \%$ in different biogas reactors).

\subsection{Biological oxygen demand (BOD)}

BOD in the agricultural waste among all the treatments was found to be highest in the treatment $\mathrm{HW}-\mathrm{T}_{4}\left(134 \mathrm{mg} \mathrm{l}^{-1}\right)$ at end of the experiment. Among treatments on par results were observed with the treatments of $\mathrm{HW}-\mathrm{T}_{3}\left(121 \mathrm{mg} \mathrm{l^{-1 }}\right)$ and $\mathrm{AW}-\mathrm{T}_{2}(181$ $\left.\mathrm{mg} \mathrm{l}^{-1}\right)$ and $\mathrm{AW}-\mathrm{T}_{1}\left(110 \mathrm{mg}^{-1}\right)$ (Table. 2$)$.

BOD content in different treatments was similar to the results of Kavya et al. (2015) who studied that variations in $B O D$ and $C O D$ at various stages of biogas production using different agricultural wastes and recorded the BOD $\left(151.75 \mathrm{~g} \mathrm{l}^{-1}, 80.14 \mathrm{~g} \mathrm{l}^{-1}\right.$ and $76.26 \mathrm{~g} \mathrm{l}^{-1}$ ) in different treatments of agricultural waste digestion process. The similar kind of results were noticed in the study conducted by Sinha and Bharambe (2008) where, they have conducted an experiment and recorded biological oxygen demand as $63.5,45.8$ and $83.2 \mathrm{mg} \mathrm{l}^{-1}$ in different treatments.

\subsection{Chemical oxygen demand (COD)}

COD in the agricultural waste among all the treatments was found to be highest in the treatment $\mathrm{HW}-\mathrm{T}_{3}\left(113 \mathrm{~g} \mathrm{l}^{-1}\right)$ at end of the experiment. Among treatments on par results were observed with the treatments of AW-T $\left(110 \mathrm{~g} \mathrm{l}^{-1}\right)$ and HW-T $4\left(110 \mathrm{~g} \mathrm{l}^{-1}\right)$ and AW-T 2 (109 $\left.\mathrm{g} \mathrm{l}^{-1}\right)$ (Table. 2).

The similar kind of results were noticed in the study conducted by Sinha and Bharambe (2008) where, they have conducted an experiment and recorded chemical oxygen demand as 112,128 , and $132 \mathrm{~g}^{-1}$ in different treatments. In the present study COD content in the horticultural waste was higher when compared to the results of Jimenez et al. (2015) who studied that A new organic matter fractionation methodology for organic wastes: bio accessibility and complexity characterization for treatment optimization and recorded the $\operatorname{COD}\left(56.90,79.50\right.$ and $\left.98.20 \mathrm{~g} \mathrm{l}^{-1}\right)$ in the digested sludge of agricultural waste in different treatments.

\subsection{Cellulose}

In all the days of intervals $\mathrm{AW}-\mathrm{T}_{2} \quad(16.56 \%)$ treatment pocesses highest cellulose content. Among treatments on par results were observed with the treatments of AW-T $(16 \%)$ and $\mathrm{HW}-\mathrm{T}_{3}(15.85 \%)$ and $\mathrm{HW}-\mathrm{T}_{4}(15.32 \%)$ (Table. 2$)$.

Lin et al. (2014) who demonstrated that comparison of solid state anaerobic digestion with effluent from liquid anaerobic digestion. The cellulose per cent in the substrates were estimated as $19.1 \%$ (in yard trimmings), $12.2 \%$ (in leaves), and $23.8 \%$ (in grass). The variation in the percentage of cellulose present in the agricultural waste substrate between different treatments at different intervals may be due to variation in chemical characteristics of substrates used and organisms involved in degradation. Similar kind of result was noticed in the study by Chen et al. (2015) where, they have recorded cellulose content was 25.61 per cent. The results of Shankarappa et al. (2015) who studied the biological pretreatment of agroresidues with lignolytic fungi for delignification and recovery of cellulose and hemicellulose was showed cellulose content was $0.32 \%$ in corn stover, $0.33 \%$ in corn husk.

\section{$3.6 \mathrm{pH}$}

Slightly acidic $\mathrm{pH}$ values recorded in $\mathrm{HW}-\mathrm{T}_{4}$ (8.48), $\mathrm{AW}-\mathrm{T}_{2}$ (8.26), AW-T 1 (8.19) and lowest $\mathrm{pH}$ was recorded in the treatment $\mathrm{HW}-\mathrm{T}_{3}$ (8.14) (Table. 2). Ideal $\mathrm{pH}$ for obtaining best biogas was 8.0-8.5 this was varied from substrate to substrate and also different from the complete process of the complete period. 
$\mathrm{pH}$ in the agriculture waste was similar to the results of Yangyang et al. (2016) who demonstrated that anaerobic digestion of corn stover in a laboratory scale reactor at mesophilic conditions $\left(35^{\circ} \mathrm{C}\right)$. The $\mathrm{pH}$ in the substrates were estimated as $7.4,7.5,7.7$ and 8.1 in agriculture waste at different treatments (corn stover digestion).

The variation in $\mathrm{pH}$ between different treatments at different intervals of biogas production may be due to variation in chemical characteristics of substrates used and organisms involved in degradation as this was noticed in the study conducted by Chandrashekara et al. (2011) where, they have recorded more $\mathrm{pH}$ (7.4) compared to biogas production produced by without inoculums (6.5) and also with microbial consortium (6.8).

Ideal $\mathrm{pH}$ for obtaining best biogas producion was 7.18.3 this was varied from substrate to substrate and also different from the complete process of anaerobic digestion process.

$\mathrm{pH}$ in the in the horticultural waste was similar to the results of Abubakar et al. (2012) who investigated the effectiveness of cow dung for biogas production and the $\mathrm{pH}$ of cow dung was in between 7.40 and 7.70 and during the anaerobic digestion there were variations between 6.12-7.70. The variation in $\mathrm{pH}$ between different treatments at different intervals of biogas production may be due to variation in chemical characteristics of substrates used and organisms involved in degradation as this was noticed in the study conducted by Chandrashekara et al. (2011).

\subsection{Total Nitrogen}

$\mathrm{N}$ content during anaerobic digestion of agricultural waste among all the treatments highest nitrogen content was recorded in the treatment $\mathrm{HW}-\mathrm{T}_{3}(1.48$ $\%$ ) and on par results were also recorded in the treatments $\mathrm{HW}-\mathrm{T}_{4}(1.28 \%), \mathrm{AW}_{-} \mathrm{T}_{2}(0.98 \%)$ and lowest nitrogen content was recorded in the treatment AW-T $1(0.76 \%)$ (Table. 2).

The similar kind of results were noticed in the study conducted by Wani et al. (2013) where they have recorded more $\mathrm{N} \%$ in cow dung $(2.03 \%)$ observed in the present experiment is similar to the results as 1.95 $\%$ and $1.91 \%$ respectively. The percentage of highest $\mathrm{N}$ content in the present work as compared with the results presented by Jeyabal et al. (2001) who studied the composition of nutrients like $\mathrm{N}, \mathrm{P}$ and $\mathrm{K}$ in biogas digested slurry and obtained the $\mathrm{N}(1.65 \%)$. The similar kind of results were noticed in the study conducted by Chandrashekara et al. (2011) where, they have recorded more nitrogen content without inoculum $(1.36 \%)$ and also with microbial consortium $(1.54 \%)$. The percentage of higher $\mathrm{N}$ per cent in the present work as compared higher results compared to the work presented by Daicy et al. (2014) who studied horticultural waste as substrates for cutting rooting and growth of rosemary and estimated the composition of nutrients like $\mathrm{N}(0.14$ and $0.15 \%)$ and $(0.15$ and $0.17 \%)$.

\subsection{Total Phosphorus}

Among all the treatments $\mathrm{P}$ content was found significantly highest in the treatment $\mathrm{HW}-\mathrm{T}_{4}(1.96 \%)$ and least was found in $\mathrm{AW}_{-} \mathrm{T}_{1}(0.17 \%)$. Among all the treatments on par results were found in the treatments $\mathrm{HW}-\mathrm{T}_{3}(1.06 \%)$ and $\mathrm{AW}-\mathrm{T}_{2}(0.19 \%)$ (Table. 2). The percentage of highest $\mathrm{P} \%$ in all the treatments from the present work as compared with the results presented by Jeyabal et al. (2001) who studied the composition of nutrients like N, P and K in biogas digested slurry recorded as $\mathrm{P}(0.70,0.76$ and $1.20 \%)$. The similar kind of results were noticed in the study conducted by Chandrashekara et al. (2011) where, they have recorded more phosphorus content in the as $(1.90 \%)$ compared to without inoculum $(1.36 \%)$ and also with microbial consortium (1.54 $\%)$.

The similar kind of results were noticed in the study conducted by Singh and Nain (2014) where, they have conducted an experiment microorganisms in the conversion of agricultural wastes.

\subsection{Total Potassium}

The available potassium in the agricultural and horticultural waste among all the treatments was found to be on par in $\mathrm{HW}-\mathrm{T}_{3}, \mathrm{HW}-\mathrm{T}_{4}(0.94$ and 0.89 $\%)$ and $\mathrm{AW}-\mathrm{T}_{2}, \mathrm{AW}-\mathrm{T}_{1}(0.78$ and $0.72 \%)$. Among all the treatments $\mathrm{K}$ content was found to be highest in the treatment $\mathrm{HW}-\mathrm{T}_{3}(0.94 \%)$ followed by $\mathrm{HW}-\mathrm{T}_{4}$ and least was found with the treatment AW-T (Table. $^{2}$ 2 ). In the results obtained as $K$ per cent in the treatments was more $(0.94,0.89,0.78$ and $0.72 \%)$ compared to the observations of Patil et al. (2011) was studied and it obtained $0.22 \%$ nitrogen and 0.20 $\%$ phosphorus.

The variation in the available potassium content between different treatments at different intervals may be due to variation in chemical characteristics of 
substrates used and efficiency of organisms involved in degradation as similar kind of results were noticed in the study conducted by Chandrashekara et al. (2011) where, they have recorded more available potassium content.

The percentage of higher $\mathrm{P}$ per cent in the present work as compared with the results presented by Jeyabal et al. (2001) who studied the composition of nutrients like $\mathrm{N}, \mathrm{P}$ and $\mathrm{K}$ in biogas digested slurry recorded as $\mathrm{P}(0.70,0.76$ and $1.20 \%)$ in cow dung, biodigested slurry and sugarcane pressmud. The nutrient states of higher P per cent in the present work as compared higher results compared to the work presented by Daicy et al. (2014) who studied horticultural waste as substrates for cutting rooting and growth of rosemary and estimated the composition of nutrients like $\mathrm{P}(0.03$ and $0.04 \%)$ and $(0.02,0.03$ and $0.04 \%)$ in different treatments.

In the above result $\mathrm{P}$ in the treatments were similar to the observations of Ewemoje et al. (2016) who investigated the nutrients level recorded the $\mathrm{P}$ in between 0.81 and $0.90 \%$. In the results obtained as $\mathrm{K}$ $\%$ in the observations of Daicy et al. (2014) was studied the horticultural waste as substrates for cutting rooting and growth of rosemary and estimated the composition of nutrients and obtained 1.74 and 1.95 $\%$ of potassium, $1.55,1.57$ and $1.62 \%$ of potassium in different treatments.

The variation in the available potassium content between different treatments at different intervals may be due to variation in chemical characteristics of substrates used and efficiency of organisms involved in degradation as similar kind of results were noticed in the study conducted by Chandrashekara et al. (2011) where, they have recorded more available potassium content without inoculum $(0.42 \%)$ and also with microbial consortium $(0.51 \%)$. In the above result $\mathrm{K}$ in the treatments were less to the observations of Ewemoje et al. (2016) who investigated the nutrients level and recorded the $\mathrm{K}$ in between 3.98 and $4.45 \%$.

\section{DISCUSSION:}

Biogas production resumption time was longer with longer low temperature duration; and increased rapidly, then decreased slightly when temperature was restored in the low temperature duration of $12 \mathrm{~h}$ and $24 \mathrm{~h}$. The delay in recovery was presumably due to the slow degradation of relatively low methaneyielding cellulosic materials. The products resulting from fermentation require an additional transformation before being able to produce methane. It is here that intervene the acetogenes reducing bacteria and the sulfato-reducing bacteria, producing hydrogen sulphide $\left(\mathrm{H}_{2} \mathrm{~S}\right)$. The ultimate phase during which two types of methanogenes bacteria take over: the first ones (acetogenes) reduce methane acetate, $\mathrm{CH}_{4}$ and bicarbonate. The second ones reduce methane bicarbonate. Rises in the methane content of biogas as a result of a decrease in the bioreactor temperature. The increase in the quality of biogas is attributed to the raised solubility of carbon dioxide at the lower temperature cycle.

The ideal biological oxygen demand (100-110 $\mathrm{mg}^{-1}$ ) was important for the maintaining anaerobic conditions and production of methane under particular bioreactor by using agricultural was as a substrate. Dissolved oxygen depletion is most likely to become evident during the anaerobic digestion, microbial population explosion in response to a large amount of organic material. If the microbial population deoxygenates the water, however, that lack of oxygen imposes a limit on population growth of microbial organisms. The ideal chemical oxygen demand (145$150 \mathrm{~g} \mathrm{l}^{-1}$ ) was important for the maintaining anaerobic conditions and production of methane under particular bioreactor by using agricultural was as a substrate. The increasing COD indicated oxygen required to oxidized substance to carbon dioxide and water. As a result of this, COD values tend to be greater than $\mathrm{BOD}$ values. COD values can be vastly greater if large amounts of biologically resistant organic matter are present.

Ideal cellulose content was $36-39 \%$ cellulolytic microorganisms can establish synergistic relationships with non-cellulolytic species in cellulosic wastes. The interactions between both populations lead to complete degradation of cellulose, releasing carbon dioxide and water under aerobic conditions, and carbon dioxide, methane and water under anaerobic conditions

The time of maximum cellulose degradation began when the digested material reached the thermophilic $\left(53-63{ }^{\circ} \mathrm{C}\right)$ phase, and this increase in the rate of cellulose degradation coincided with the emergence of the actinomycetes as a major population.

Different habitats in which cellulose is widely available, by their differing characteristics (water availability, oxygen availability, redox potential, 
temperature variability, and nutrient status) have fostered the development of cellulose utilization strategies that differ in enzyme architecture and presentation, rate and extent of cellulolysis, ancillary hydrolytic activities, fate of hydrolytic products, and interactions among cellulolytic and non-cellulolytic microbes. Among the aerobic bacteria from other substrates, actinobacteria probably play a major role in the degradation of lignocelluloses. These bacteria can degrade cellulose and solubilize lignin. However, it seems that thermophilic and thermotolerant fungi, which are known to have cellulolytic and ligninolitic activity, are critical to the degradation of lignocellulosic materials.

More increase in phosphorus in different treatments is probably due to mineralization and mobilization of phosphorus due to microbial population. During organic matter decomposition by the microorganisms is the major mechanism for solubilisation of insoluble phosphorus, which subsequently results in increase in phosphorus content.

The digestion system and conditions, characteristics of both the bedding material and the bulking agent added for digestion and even the environmental conditions of the season have a great influence on the mineralisation of the organic matter. During the active phase of the this process the organic carbon decreases in the material due to decomposition of the organic matter by the microorganisms. This loss of organic matter reduces the weight of the pile and decreases the $\mathrm{C} / \mathrm{N}$ ratio. The degradation rate of the organic matter decreases gradually as the progresses because of the reduction in available carbon sources, and synthesis reactions of new complex and polymerised organic compounds (humification) prevail over mineralisation during the maturation phase.

\section{CONCLUSION:}

Samples were collected from different sources i.e. Student farm, farmer's fields, forest soil, horse dung dump, domestic kitchen waste, municipal solid waste, sewage water and cow dung. They were further tested qualitatively and quantitatively for cellulase activity. Among thirty isolates, four bacterial isolates were having maximum cellulase activity. Finally these four isolates were selected for pretreatment of agricultural (Maize straw) and horticultural waste (Banana fruit waste) for biogas production under anaerobic condition after enriching the substrates with cellulose degrading cultures. Biological pretreatment with complex microbial agents proved to be an efficient method to improve biodegradability to enhance biogas production of agricultural waste and horticultural waste. Compared to untreated controls the pretreated agricultural and horticultural waste yielded higher manurial value and given more biogas production. The enhanced biogas production was attributed to the improved biodegradability of the straw and fruit waste as indicated by increased TS and VS reductions and a shortened digestion time. By the pretreatment of agricultural waste, horticultural waste were easily degraded by enriched cultures and their enzyme activities. The N, P and organic carbon \% increased in all the treatments of horticultural waste compared to agricultural waste. Considering the characteristics of the high moisture solid waste of agricultural and horticultural waste, anaerobic digestion represents a feasible and effective method to convert the waste to biogas fuel. The agricultural waste was found to be the best in biogas production as compared to horticultural waste. Horticultural waste was comparatively better in terms of N, P, K and organic carbon $\%$.

\section{ACKNOWLEDGEMENTS:}

I take opportunity to thank all those who contributed in the successful completion of my research work smoothly. I would like to express my sincere thanks to my chairman and members of my advisory committee and Department of Agricultural Microbiology and Bioenergy, College of agriculture, Rajendranagar, Hyderabad for their valuable guidance and constant encouragement during the entire process of my work and making my paper. I also thank all teaching and non-teaching staff who directly or indirectly helped me for the completion of this paper.

\section{REFERENCES:}

1) Abubakar, B.S.U.I and Ismail, N. 2012. Anaerobic digestion of cowdung for biogas production. ARPN Journal of Engineering and Applied Sciences. 2 (7): 169-172.

2) Amon, B., Amon, T., Kryvoruchko, V., Zollitsch, K.M and Gruber, L. 2007. Biogas production from maize and dairy cattle manure: influence of biomass composition on the methane yield. Agriculture, Ecosystems \& Environment. 118: 173-182.

3) Andro, T., Chambost, J.P., Kotoujansky, A., Cattane, J., Bertheau, Y., Barras, F., Van, GiIsegem, F and Coleno, A. 1984. Mutants of Erwinium Chrysunthemi defective in secretion of 
pectinase. Journal of Bacteriology 160: 11991203.

4) APHA. 1992. Standard methods for the examination of water and wastewater, $18^{\text {th }}$ edition. Washington, DC: American Public Health Association. Biotechnology. 85 (4): 849-860.

5) Bailey, M.J., Biely, $P$ and Poutanen, K. Inter laboratory testing of methods for assay of xylanase activity. Journal of Biotechnology. 23: 257-270.

6) Borjesson, P and Berglund, M. 2006. Environmental systems analysis of biogas system Part I: Fuel cycle emissions, Biomass and Bioenergy. 30: 469-485.

7) Busch et al. 2009. A New and Sound Technology for Biogas from Solid Waste and Biomass, Water Air Soil Pollution. 89-97.

8) Chandrashekara, U.M., Balasundaran, M., Baiji, E.C and Nishad, V.M. 2011. Combined effect of microbes and earthworms on compost and its influence on crop growth and yield. Journal of Soil Biology and Ecology. 31 (1\&2): 183-194.

9) Chen, Y., Yufen, Z., Quanguo, Z., Lixin, X., Ran, L., Xiaopei, L., Xin, Z and Jin, T. 2015. Earthworms modify microbial community structure and accelerate maize stover decomposition during vermicomposting. Environmental Science Pollution Research. 22: 17161-17170.

10) Daicy, M.H., Fornes, F., Belda, R.M. 2014. Compost and vermicompost of horticultural waste as substrates for cutting rooting and growth of rosemary. Scientia Horticulturae. 178: 192-202.

11) Ewemoje, O.E., Ewemoje, T.A and Adedeji, A.A. 2016. Comparative analysis of pit composting and vermicomposting in a tropical environment. International Journal of Biological, Biomolecular, Agricultural, Food and Biotechnological Engineering. 10 (3): 152-155.

12) Gautam, S.P., Bundela, P.S., Pandey, A.K., Jamaluddin, M.K., Awasthi and Sarsaiya, S. 2012. Diversity of cellulolytic microbes and the Biodegradation of municipal solid waste by a potential strain. International Journal of Microbiology. 12: 1-12.

13) Hansen, L.C and Cheong, D.Y. 2007. Agricultural Waste Management in Food Processing,
Handbook of Farm, Dairy and Food Machinery. 609-661.

14) Jackson, M.L. 1967. Soil chemical analysis. Prentice Hall of India, Ltd, New Delhi. 498.

15) Jackson, M.L. 1973. Soil chemical analysis. Prentice Hall of India, Ltd, New Delhi. 60: 7-33.

16) Jeyabal, A and Kuppuswamy, G. 2001. Recycling of organic wastes for the production of vermicompost and its response in rice-legume cropping system and soil fertility. European Journal of Agronomy. 15: 153-170.

17) Jimenez, J., Aemig, Q., Doussiet, N., JeanPhilippe, S., Houot, S and Patureau, D. 2015. A new organic matter fractionation methodology for organic wastes: bio accessibility and complexity characterization for treatment optimization. Bioresource Technology. 194: 344-353.

18) Kavya, Y., Vijaya gopal, A., Reddy, R.S and Sailaja rani, J. 2015. Variations in BOD and COD at various stages of biogas production using different agricultural wastes. Journal of Plant Development Sciences. 7 (6): 511-513.

19) Lin, L., Liangcheng, Y., Fuqing, Xu., Frederick, C., Michel and Yebo, Li. 2014. Comparison of solid-state anaerobic digestion and composting of yard trimmings with effluent from liquid anaerobic digestion. Bioresource Technology. 169: 439-446.

20) Maranon, E., Castrillon, L., Quiroga, G., Fernandez-Nava, Y., Gomez, L and Garcia, M.M. 2012. Co-digestion of cattle manure with food waste and sludge to increase biogas production. Waste Management. 32: 1821-1825.

21) Miller, G.A.I.L. 1959. Use of Dinitrosalicylic acid reagent for detection of reducing sugars. Analytical Chemistry. 31 (3): 426-428.

22) Patil, J.H., Raj, M.A., Gavimath, C.C and Vinay, R., Hooli, V.R. 2011. A comperative study on anaerobic co-digestion of water hyacinth with poultry litter and cow dung. International Journal of Chemical Sciences and Applications. 2 (2): 148-155.

23) Peter, W. 2009. Biogas production: current state and perspectives, Applicated Microbiology

24) Shankarappa, T.H., Geeta, G.S., Narotham, P.B.D., Doddagoudar, C.K and Alagawadi, A.R. 2015. Biological pretreatment of agroresidues 
with lignolytic fungi for delignification and recovery of cellulose and hemicellulose. International Journal of Current Microbiology and Applied Sciences. 4 (9): 22-30.

25) Shoham, Y., Lamed, R and Bayer, E. 1999. The cellulosome concept as an efficient microbial strategy for the degradation of insoluble polysaccharides. Trends in Microbiology. 7 (7): 275-281.

26) Singh, S and Nain, L. 2014. Microorganisms in the conversion of agricultural wastes to compost. Proceedings of the Indian National Science Academy. 80 (2): 473-481.

27) Sinha, R.K., Bharambe, G and Chaudhari, U. 2008. Sewage treatment by vermifiltration with synchronous treatment of sludge by earthworms: a low-cost sustainable technology over conventional systems with potential for decentralization. Environmentalist. 28: 409-420.

28) Updegraff, D.M. 1969. Semimicro determination of cellulose in biological materials. Analytical Biochemistry. 32: 420-424.
29) Vikrant, D and Shekhar, P. 2013. Generation of biogas from kitchen waste-experimental analysis. International Journal of Engineering Science Invention. 2 (10): 15-19.

30) Wani, K.A., Mamta, and Rao, R.J. 2013. Bioconversion of garden waste, kitchen waste and cow dung into value-added products using earthworm Eisenia fetida. Saudi Journal of Biological Sciences. 20: 149-154.

31) Yangyang, Li., Li, Y., Zhang, D., Li, G., Lu, J and Li, S. 2016. Solid state anaerobic co-digestion of tomato residues with dairy manure and corn stover for biogas production. Bioresource Technology. 16.

32) Yin, H., Zhao, X. and Du, Y. 2010. Oligochitosan: A plant diseases vaccine-A review. Carbohydrate Polymers. 82: 1-8.

33) Ziganshin, A.M., Liebetrau, J., Proter, J and Kleinsteuber, S. 2013. Microbial community structure and dynamics during anaerobic digestion of various agricultural waste materials. Applied Microbiology and Biotechnology. 97: 5161-5174. 